\title{
The high costs of for-profit care
}

\author{
Steffie Woolhandler, David U. Himmelstein
}

ß See related article page 1817

A S we have written elsewhere, ${ }^{1}$ some aspects of life are too precious, intimate or corruptible to entrust to the market. We prohibit selling kidneys and buying wives or judges. But the market has unquestionably gained new territory in recent years, as more and more activities previously performed by government or nonprofit agencies - including interrogating Iraqi prisoners - have been turned over to private enterprise. For ordinary citizens, the drive to privatize is most evident in health care. In the United States, investor-owned firms have come to dominate renal dialysis, nursing home care, inpatient psychiatric and rehabilitation facilities and health maintenance organizations (HMOs). They have made significant inroads among acute care hospitals (now owning about 13\% of such facilities), as well as outpatient surgical centres, home care agencies and even hospices. Canada has lagged behind the United States, but by increments the private delivery of publically funded services increases. The for-profit barbarians are at the gates.

Those who favour for-profit health care argue that the profit motive optimizes care and minimizes costs. In this issue P.J. Devereaux and colleagues ${ }^{2}$ add to the considerable evidence that this dogma has no clothes. Their meticulous meta-analysis demonstrates a pattern of higher payments for care in private, investorowned hospitals as compared with private not-for-profit hospitals. The only significant exception was a small study comparing private for-profit hospitals with nominally not-for-profit hospitals run by a private, for-profit firm - in other words, both groups of hospitals in this study were under for-profit management.

The excess payments for care in private for-profit institutions were substantial: $19 \%$. This figure implies that the US\$37 billion that Americans paid for care at investorowned acute care hospitals in $2001^{3}$ would have cost only US\$3 1 billion at not-for-profit hospitals - a waste of US\$6 billion. But higher acute care (and rehabilitation ${ }^{4}$ ) hospital payments are not the whole story on investorowned care. For-profit hospitals and dialysis clinics have high death rates. ${ }^{5,6}$ Investor-owned nursing homes are more frequently cited for quality deficiencies and provide less nursing care, ${ }^{7}$ and investor-owned hospices provide less care to the dying, ${ }^{8}$ than non-for-profit facilities.

Why does investor ownership increase costs? Investorowned hospitals are profit maximizers, not cost minimizers. Strategies that bolster profitability often worsen efficiency and drive up costs. Columbia/HCA, the largest hospital firm in the United States, has paid the US government US\$1.7 billion in settlements for fraud, the payment of kickbacks to physicians and overbilling of Medicare. Tenet, the second largest US hospital firm, paid more than half a billion dollars to settle charges of giving kickbacks for referrals and inappropriately detaining psychiatric patients to fill beds during the 1980s, when the firm was known as NME. ${ }^{10}$ In March 2004, Tenet agreed to pay the US government US\$22.5 million to settle one of several cases; ${ }^{11}$ recent allegations against them have included performing cardiac procedures on healthy patients, offering kickbacks for referrals and exploiting Medicare loopholes to claim hundreds of millions in undeserved payments.

For-profit executives reap princely rewards, draining money from care. When Columbia/HCA's CEO resigned in the face of fraud investigations, he left with a $\$ 10$ million severance package and $\$ 324$ million in company stock. ${ }^{12}$ Tenet's CEO exercised stock options worth \$111 million shortly before being forced out in $2003,{ }^{13}$ and the head of HealthSouth (the dominant provider of rehabilitation care) made $\$ 112$ million in 2002,,$^{13}$ the year before his indictment for fraud.

Enormous CEO incomes explain part, but not all, of the high administrative costs at investor-owned health care firms. Investor-owned hospitals spend much less on nursing care than not-for-profit hospitals, but their administrative costs are 6 percentage points higher ${ }^{14}$ (presumably reflecting their more meticulous attention to financial details).

High administrative costs and lower quality have also characterized for-profit HMOs, ${ }^{15}$ now the dominant private insurers in the United States. Such plans take 19\% for overhead, versus $13 \%$ in non-profit plans, $3 \%$ in the US Medicare program and $1 \%$ in Canadian medicare. ${ }^{16,17}$ Strikingly, contracting with private HMOs has substantially increased US Medicare costs. For the past decade, Medicare has paid HMO premiums for seniors choosing to enroll in such private plans. According to official estimates, the HMOs have recruited healthy seniors who, had they not switched to an HMO, would have cost Medicare little about \$2 billion less annually than the HMOs' premiums. ${ }^{17}$ Private plans that were unable to recruit healthy people dropped out of their Medicare contracts, disrupting care for millions of seniors. Washington's response? Sweeten the pot for Medicare HMOs by including $\$ 46$ billion to raise $\mathrm{HMO}$ payments as part of the recently enacted Medicare prescription drug bill. ${ }^{18}$

Why do for-profit firms that offer inferior products at inflated prices survive in the market? Several prerequisites for the competitive free market described in textbooks are absent in health care..$^{19,20}$

First, it is absurd to think that frail elderly and seriously ill patients, who consume most care, can act as informed 
consumers (i.e., comparison-shop, reduce demand when suppliers raise prices or accurately appraise quality). Even less vulnerable patients can have difficulty gauging whether a hospital's luxurious appurtenances bespeak good care.

Second, the "product" of health care is notoriously difficult to evaluate, even for sophisticated buyers like government. Physicians and hospitals create the data used to monitor them; self-interest puts the accuracy of such data into question. By labelling minor chest discomfort "angina" rather than "chest pain," a US hospital can garner both higher Medicare payments and a factitiously improved track record for angina treatment. It is easier and more profitable to exploit such loopholes than to improve efficiency or quality.

Even for honest firms, the careful selection of lucrative patients and services is the key to success, whereas meeting community needs often threatens profitability. For example, for-profit specialty hospitals offering only cardiac or orthopedic care (money-makers under current payment schemes) have blossomed across the United States. Most of these new hospitals duplicate services available at nearby not-for-profit general hospitals, but the newcomers avoid money-losing programs such as geriatric care and emergency departments (a common entry point for uninsured patients). The profits accrue to the investors, the losses to the not-for-profit hospitals, and the total costs to society rise through the unnecessary duplication of expensive facilities.

Finally, a real market would require multiple independent buyers and sellers, with free entry into the marketplace. Yet, many hospitals exercise virtual monopolies. A town's only hospital cannot compete with itself, but can use its market power to inflate its earnings. Not surprisingly, for-profit hospital firms in the United States have concentrated their purchases in areas where they can gain a large share of the local market. Moreover, many health care providers and suppliers enjoy state-conferred monopolies in the form of licensure laws for physicians and hospitals and patent protection for drugs. Additionally, government pays most health costs - even in the United States. ${ }^{21}$ Indeed, public funding for health care in the United States exceeds total health spending in Canada on a per capita basis. It's an odd market that relies largely on public funds.

Privatization results in a large net loss to society in terms of higher costs and lower quality, but some stand to gain. Privatization creates vast opportunities for powerful firms, and also redistributes income among health workers. Pay scales are relatively flat in government and not-for-profit health institutions; pay differences between the CEO and a housekeeper are perhaps 20:1. In US corporations, a ratio of 180:1 is average. ${ }^{22}$ In effect, privatization takes money from the pockets of low-wage, mostly female health workers and gives it to investors and highly paid managers.

Behind false claims of efficiency lies a much uglier truth. Investor-owned care embodies a new value system that severs the community roots and Samaritan traditions of hospi- tals, makes physicians and nurses into instruments of investors, and views patients as commodities. Investor ownership marks the triumph of greed.

From the Department of Medicine, Cambridge Hospital/Harvard Medical School, Cambridge, Mass.

Competing interests: None declared.

Contributors: Both authors contributed equally to the conception, research and writing of this editorial.

\section{References}

1. Woolhandler S, Himmelstein DU. When money is the mission - the high costs of investor-owned care. N Engl f Med 1999;341:444-6.

2. Devereaux PJ, Heels-Ansdell D, Lacchetti C, Haines T, Burns KEA, Cook DJ, et al. Payments for care at private for-profit and private not-for-profit hospitals: a systematic review and meta-analysis. CMA7 2004;170(12):1817-24.

3. American Hospital Association. Hospital statistics 2003. Chicago: The Association; 2003.

4. Chan L, Koepsell TD, Deyo RA, Esselman PC, Haselkorn JK, Lowery JK, et al. The effect of Medicare's payment system for rehabilitation hospitals on length of stay, charges and total payments. N Engl f Med 1997;337(14):978-85.

5. Devereaux PJ, Schunemann HJ, Ravindran N, Bhandari M, Garg AX, Choi PT, et al. Comparison of mortality between private for-profit and private notfor-profit hemodialysis centers: a systematic review and meta-analysis. $7 A M A$ 2002;288(19):2449-57.

6. Devereaux PJ, Choi PT, Lacchetti C, Weaver B, Schunemann HJ, Haines T, et al. A systematic review and meta-analysis of studies comparing mortality rates of private for-profit and private not-for-profit hospitals. CMAF 2002;166(11):1399-406.

7. Harrington C, Woolhandler S, Mullan J, Carrillo H, Himmelstein DU. Does investor ownership of nursing homes compromise the quality of care? $A m \mathcal{F}$ Public Health 2001;91:1452-55.

8. Carlson MDA, Gallo WT, Bradley EH. Ownership status and patterns of care in hospice: results from the National Home and Hospice Care Survey. Med Care 2004;42:432-8.

9. Justice Dept. Civil fraud recoveries total \$2.1 billion for FY 2003. False Claim Act recoveries exceed $\$ 12$ billion since 1988 [media release]. US Department of Justice 2003 Nov 10. Available: www.usdoj.gov/opa/pr/2003/Novem ber/03_civ_613.htm (accessed 2004 May 17).

10. Eichenwald K. \$100 million settlement seen in Tenet suits. New York Times 1997 Jul 30;D1.

11. Tenet Healthcare to pay U.S. \$22.5 million for improperly billing Medicare [media release]. US Department of Justice, 2004 Mar 24. Available: www.us doj.gov/opa/pr/2004/March/04_civ_183.htm (accessed 2004 May 17).

12. Lowry T. Columbia's new caretaker physician heal thy firm: tall task ahead of CEO. USA Today [Virginia] 1997 Jul 28;1B.

13. Galloro V, Benko LB. Are they worth it? Executive compensation, company performance don't always relate at top hospital, post-acute and insurance companies. Mod Healthc 2003;4:6-14.

14. Woolhandler S, Himmelstein DU. Costs of care and administration at forprofit and other hospitals in the United States. N Engl 7 Med 1997;336:769-74.

15. Himmelstein DU, Woolhandler S, Hellander I, Wolfe SM. Quality of care in investor-owned vs not-for-profit HMOs. FAMA 1999;282:159-63.

16. Woolhandler S, Campbell T, Himmelstein DU. Costs of health care administration in the United States and Canada. N Engl 7 Med 2003;349:768-75.

17. Risk selection and risk adjustment in Medicare. Chapter 15. In: Annual Report to Congress. Washington (DC): Physician Payment Review Commission;1996.

18. Pear R. Medicare actuary gives wanted data to Congress. New York Times 2004 Mar 20;A8.

19. Evans RG. Going for the gold: the redistributive agenda behind market-based health care reform. 7 Health Polit Policy Law 1997;22:427-66.

20. Rice T. Can markets give us the health system we want? 7 Health Polit Policy Law 1997;22:383-426.

21. Woolhandler S, Himmelstein DU. Paying for national health insurance - and not getting it: taxes pay for a larger share of U.S. health care than most Americans think they do. Health Aff 2002;21(4):88-98.

22. Belsen K. Executive pay: a special report: learning how to talk about salary in Japan. New York Times 2002 Apr 7;12.

Correspondence to: Steffie Woolhandler, Cambridge Hospital, 1493 Cambridge St., Cambridge MA 02139; fax: 617 665-1671; steffie_woolhandler@hms.harvard.edu 